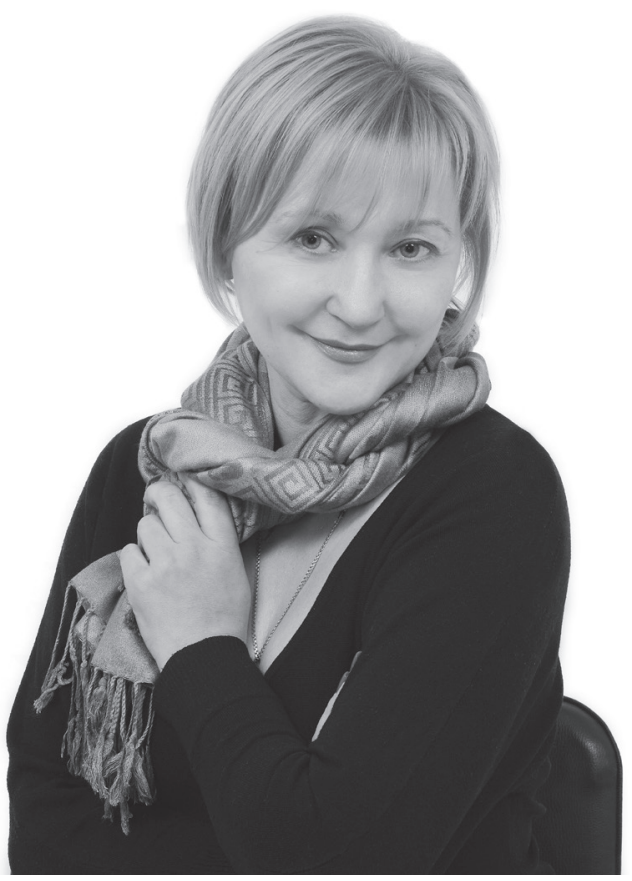

(067) 56430 08, e-mail:yartala28@gmail.com

Kolomiets Natalia Yevheniivna,

PhD of philological sciences, KryvyiRih State Pedagogical University, 50086, Krivoy Rog, Prospect Gagarina, 54, tel.: +3(067) 94008 14, e-mail: natagh2012@ukr.net

ORCID: 0000-0001-5455-2538

Коломієць Наталія Свгенівна,

кандидат філологічних наук, дощент, ДВНЗ “Криворізький державний педагогічний університет”, 50086, м. Кривий Ріг, просп. Гагаріна, 54, тел.: +3(067) 94008 14, е-таіl: natagh2012@ukr.net

ORCID: 0000-0001-5455-2538

Коломиеи, Наталия Евгенвевна, кандидат филологических наук, дочент, ГВУЗ “Криворожский государственньй педагогический университет”, 50086, г. Кривой Рог, просп. Гагарина, 54, тел.: +3(067) 940 08 14, email: natagh2012@ukr.net

ORCID: 0000-0001-5455-2538

\title{
PEDAGOGICAL EMPOWERMENT AS A MODEL OF HARMONIZATION OF PSYCHO-CULTURAL COMPLEXES "PUER" ARCHITECTURE CREATION OF THE PRIZE OF STRATEGY FOR SUSTAINABLE DEVELOPMENT
}


Abstract. The article attempts to clarify the specifics of practical implementation of empowerment-pedagogy in order to harmonize the psycho-cultural components of the archetype "puer" through the prism of the strategy of sustainable development, adopted in September 2015 by the decision of the General Assembly of the United Nations. Among the main provisions, it is indicated that the creation of a new educational paradigm is crucial for realizing the potential of the future, which will contribute to the formation of a responsible person capable of making the world safe and comfortable.

The acrticle established that the change in the paradigm of social consciousness caused the necessity of transforming the education system, since the future potential is formed in the process of formation of the child's personality. There is no doubt that the formation of sustainable development requires updating of existing pedagogical models, filling them with new content, aimed at forming the system of views, habits, lifestyle that corresponds to modern tendencies in the students. It is revealed that at the present stage, an appeal to the pedagogy of the empowerment, which focuses on the direction of the younger generation to action, the achievement of personal progressive changes, is important.

In exploration it was observed that the content of this approach is empowerment, the acquisition of individual self-confidence, the disclosure deep potential mobilization of internal resources under conditions of trust partnerships in any dialogue. Since the same archetype "divine child" is a kind of matrix potential collective unconscious experience, it is a modern life stream adaptation that should be the basis for implementing the requirements of social and cultural life. The authors emphasize that today's needs correspond most closely to such an approach, which contributes to the disclosure of the creative potential of the younger generation, the improvement of the effectiveness of learning, the acquisition of skills to competences that a modern, dynamic world requires.

Keywords: empowerment-pedagogy, archetype, Puer, Sustainable Development Program.

\section{ЕМПАУЕРМЕНТ-ПЕДАГОГІКА ЯК МОДЕЛЬ ГАРМОНІЗАЦЇ ПСИХОКУЛЬТУРНИХ СКЛАДОВИХ АРХЕТИПУ “РUЕR” КРІЗЬ ПРИЗМУ СТРАТЕГЇ̈ СТАЛОГО РОЗВИТКУ}

Анотація. Зроблено спробу з'ясувати особливості практичного втілення емпауермент-педагогіки з метою гармонійного узгодження психокультурних складових архетипу "рuer" крізь призму стратегії сталого розвитку, ухваленої у вересні 2015 р. рішенням Генеральної Асамблеї ООН. Серед головних положень зазначено, що для реалізації потенціалу майбутнього вирішальним є створення нової освітньої парадигми, яка сприятиме формуванню відповідальної особистості, здатної зробити світ безпечним і комфортним. Встановлено, що зміна парадигми суспільної свідомості зумовила необхідність трансформації системи освіти, оскільки потенціал прийдешнього формується в процесі становлення особистості дитини. Безперечно, що освіта сталого розвитку потребує оновлення існуючих педагогічних моделей, наповнення 
ïx новим контентом, спрямованим на формування в учнів системи поглядів, звичок, стилю життя, які відповідають сучасним тенденціям. Виявлено, що на нинішньому етапі важливим є звернення до педагогіки емпауерменту, яка орієнтована на спрямування молодого покоління до дій, досягнення особистісних прогресивних змін. У розвідці спостережено, що змістом подібного підходу є наснаження, набуття особистістю впевненості у власних силах, розкриття глибинного потенціалу, мобілізація внутрішніх ресурсів за умов довірчих партнерських стосунків у будь-якому діалозі. Оскільки ж саме архетип "Божественна дитина" є своєрідною матрицею потенціалу колективного безсвідомого досвіду, саме його адаптація в сучасному житєвому потоці має стати базисом для реалізації соціокультурних вимог буття. Авторами акцентовано, що потребам сьогодення найбільше відповідає подібний підхід, як такий, що сприяє розкриттю творчого потенціалу молодого покоління, покращенню результативності навчання, набуття навичок до компетенцій, які потребує сучасний динамічний світ.

Ключові слова: емпауермент-педагогіка, архетип, Пуер, Програма сталого розвитку.

\section{ЭМПАУЭРМЕНТ-ПЕДАГОГИКА КАК МОДЕЛЬ ГАРМОНИЗАЦИИ ПСИХОКУЛЬТУРНЫХ СОСТАВЛЯЮЩИХ АРХЕТИПА "РUЕR" СКВОЗЬ ПРИЗМУ СТРАТЕГИИ УСТОЙЧИВОГО РАЗВИТИЯ}

Аннотация. Сделана попытка выяснить особенности практического воплощения эмпауэрмент-педагогики с целью гармонизации психокультурных составляющих архетипа "рuer" сквозь призму стратегии устойчивого развития, принятой в сентябре 2015 г. решением Генеральной Ассамблеи ООН. Среди основных положений указано, что для реализации потенциала будущего решающим является создание новой образовательной парадигмы, которая будет способствовать формированию ответственной личности, способной сделать мир безопасным и комфортным. Установлено, что изменение парадигмы общественного сознания обусловила необходимость трансформации системы образования, поскольку потенциал будущего формируется в процессе становления личности ребенка. Бесспорно, что образование устойчивого развития нуждается в обновлении существующих педагогических моделей, наполнение их новым контентом, направленным на формирование системы взглядов, привычек, образа жизни, которые соответствуют современным тенденциям. Выявлено, что на нынешнем этапе важным является обращение к педагогике эмпауэрмента, ориентированной на пробуждение молодого поколения к действиям, достижению личностных прогрессивных изменений. В статье обнаружено, что содержанием подобного подхода является вдохновение, приобретение личностью уверенности в собственных силах, раскрытие глубинного потенциала, мобилизация внутренних ресурсов в условиях доверительных партнерских отношений в любом диалоге. Поскольку же архетип "Божественный ребенок" является своеобразной матрицей потенциала коллективного бессознательного опыта, именно его 
адаптация в современном жизненном потоке должна стать базисом для реализации социокультурных требований бытия. Авторами акцентировано, что сегодняшним потребностям наиболее соответствует подобный подход, как таковой, что способствует раскрытию творческого потенциала молодого поколения, улучшению результативности обучения, приобретение навыков к компетенциям, в которых нуждается современный динамичный мир.

Ключевые слова: эмпауэрмент-педагогика, архетип, Пуэр, Программа устойчивого развития.

Problem statement. The multidimensional transformation of the socio-cultural life of modern Ukraine is conditioned by the influence of integrational world processes, the approach to the values of the European community and the actualization of deep layers of the national potential. The substantial reforming of educational strategy occurs, which is a core of intellectual, cultural, spiritual development of the state under such conditions. The current state of modernization of society as a whole and education as a significant factor is predefined to a great extent to the implementation of the Sustainable Development Program, which orientates people to continuous training in a dynamic world, the harmonious comprehensive development of representatives of various articles, inspiration, and others. Similar inquiries appeared before a modern man on the way to achievement of vital success determine the permanent updating, an indispensable intellectual growth of personality.

American futurist A. Toffler outlined the changes that must take place in a person of the era of global changes: "The technology of tomorrow requires not millions of superficially well-read people who are ready to work in unison on endless monotonous works, not people who carry out orders without blinking their eyes $\langle\ldots\rangle$, but the people capable of making critical decisions who can find their way in a new environment, which quickly establish new relationships in a rapidly changing reality" [1, p. 328].

The re-accentuation of society from industrial to information actualizes the need to create a modern educational paradigm that will serve as the basis for the cultural and civilized progress of the state, and will be aimed at generating information and presenting creative ideas. At the present stage of the transformation of society, it is important to appeal to the empowering pedagogy, which focused on the direction of the young generation to actions, the achievement of personality changes. The content of similar approach is inspiration, personal self-confidence, the disclosure of deep potential, mobilization of internal resources under confiding partner relations in any dialogue. The needs of today are best met by a similar approach, as such, which helps to unleash the creative potential of the younger generation and improve the effectiveness of training.

\section{Analysis of recent research and} publications. The problem of empowering pedagogy as a direction to educational strategy in the interests 
of sustainable development in the center of scientific research has arisen until recently. The emergence of this theoretical concept is associated with the activities of the Brazilian scientist P. Freire (late twentieth century). Modern researches raise the question of the essence of the term "empowerment", the peculiarities of its functioning (N. Kryvokon, O. Müllender, D. Ward, T. Sila, and others). The application of methods of empowerment in psychology and social work have been paid attention by R. Armando, S. Geno, N. Kryvokon and others.

N. Vovk, M. Zhukova, N. Myskova, $\mathrm{N}$. Telychko and others addressed the practical implementation of the ideas of empowering pedagogy in the educational process.

The purpose of the article is to find out the peculiarities of the practical implementation of empowering pedagogy with the purpose to harmonize the psycho-cultural components of the "puer" archetype through the prism of a sustainable development strategy.

Statement of the main material. Searching for ways to solve the global socio-environmental crisis that unfolded in the second half of the twentieth century has intensified precisely in the new style formation for a civilized human behavior in everyday life, aimed at a rational attitude towards the environment and other members of the world community. In particular, the acute problem of searching for ways appeared sharply in developing such global community that, while meeting its urgent needs, would not jeopardize the possibilities of future generations.

The main principles of the Sustainable Development Program were for- mulated during the Second United Nations Conference dedicated to the solution of environmental safety issues (Rio de Janeiro, 1992). It is indicated among the main principles that in order to realize the potential of the future, it is crucial to create a new educational paradigm that will contribute to the formation of a responsible person capable of making the world safe and comfortable. The UN World Summit in Johannesburg (South Africa, 2002) formulated the concept of education for sustainable development, based on the requirement to revise the educational process in order to implement the foundations and values of sustainable development in the educational space. Ukraine had joined the Fifth UNECE Environment Ministers Conference "Environment for Europe" (Kyiv, 2003) to this end, recognized it is education that the leading means of promoting the organic interaction between humans and the environment, sustainable development. The Ministers have approved the Statement of Education in favor of sustainable development and proposed to include the concept of sustainable development in the national educational environment at all levels to enhance positive transformations.

The draft Strategy for Sustainable Development of Ukraine for the period until 2030 defines that "a balanced society is a knowledge society. New knowledge, skills and competences are needed to solve many development problems, to understand the complex issues and solve interrelated issues of public life" [2]. According to the principles of the "UNECE Education for Sustainable Development Strategy" adopted in Vilnius in 2005, a person, regardless of 
"ethnic or social origin, property status, place of residence, language or other signs, will have access to high-quality education, health care system and other services in the public and private sectors" [3].

It is indisputable that the education of sustainable development needs to update the existing pedagogical models, filling them with new content aimed at forming a system of attitudes, habits, and lifestyle for the students, which correspond to modern trends. According to T. Kovalenko, " $<$...> the following principles were laid down at the legislative level in Ukraine since 1991: the priorities of the interests of the child; ensuring the full life of children; involvement of children in the community life and proclaiming the absence of any manifestation of discrimination against children in Ukraine" [4, p. 109]. Similar assertions prove the idea that all the essential moral and ethical ideas that dominate in the society are rooted in archetypes. Prospective development of the future progress of mankind aiming at the development of a holistic harmonious model becomes possible, to our opinion, subject to that the regulatory role of the archetypes in which the mental in man is encoded, " $<$...> its historical experience and helplessness, despair and confidence, loneliness and collectivity, uniqueness and standardization, uniqueness and all-humanity" [5, p. 195]. Appealing to the "puer" archetype within the framework of the concept of sustainable development makes it possible to build a panoramic projection of the transformation of the cultural experience of mankind.

The empowering pedagogy originates from the ideas outlined in the work "Pedagogy of the oppressed" by Brazilian scientist P. Freire, who focused on the need to awaken the selfidentity of the individual in order to gain knowledge. Since the practice of enslaving is based on the idea of submission, isolation, keeping a person in a passive state, deepening the distance between people, the researcher emphasized the need for transformation, the way out of the situation of depersonalization, the search for inner support in order to " $<\ldots>$ change their weakness to the transformational force with which they can change the world and make it more humane" [6, p. 127].

According to the scientist, such transformations are possible under the condition of the pedagogy of cooperation based on the dialogue: "Since the liberation activity is a dialogue in its nature, the dialogue cannot be a consequence of this activity, but should accompany it. And since the liberation should be a continuous condition, the dialogue becomes the aspect of the liberation activity that is constantly ongoing" [6, p. 120].

The concept of "empowerment" has received various interpretations in the aspect of the liberation of individual consciousness: the liberation of individual through transformation in the educational process; overcoming various forms of domination of people in society; gender equality; the acquisition of potency by socially depleted groups of people; recognition of various social groups, subcultures, etc. Thus, the characteristic modes of this concept are the measurement of power (as potencies to influence the course of events), cooperation without hierarchical barriers and the learning process, during which the 
self-realization skills of personality are formed.

According to N. Telychko, pedagogical empowerment can be described as "the art of creating life that a person seeks to live; as a way of forming a viable personality, noting that this aspect in activity is intended for people who are ready to bring themselves to the forefront of self-development; as a process of preparing a person for independent actions" [7, p. 199].

The strategy of pedagogical empowerment is applied with the purpose of obtaining such skills and qualities by the participants of the educational process as independence in making decisions, ability to active social life, self-change in accordance with the demands of society for success, etc. Firstly, the fulfillment of inspiration occurs by forming a positive attitude of a student towards oneself and faith in the potential, the development of basic skills and functional capabilities. Secondly, psycho-emotional shifts, indicators of which are adaptation in stressful environments, lack of fear in communication, overcoming asthenical feelings, optimism, a self-confidence, etc. Thirdly, the practical application of a behavioral model of organizing educational activities based on the motivation for success, dedication, life activity, the willingness to express one's own opinion, to defend one's position and listen to the opinions of others, and the like.

The harmonious adjustment of the psycho-cultural components of the "puer" archetype is seen as possible with a bearing on the empowering pedagogy. The problems of providing inner strength in the process of informational interaction of the individual, society and nature, formation of a critical, creative look at the urgent issues of the day are actualized at this angle. The development of the modern child occurs in conditions of redundancy of information, lack of parental attention, lack of a sense of security, which leads to the destruction of emotional contact, constant adaptation to the conditions of society. The inspiration contributes to the depiction of worldview orientations, the formation of positive motivation in obtaining knowledge, developing the ability to make extraordinary decisions, etc.

The methodical basis of classes, during which the arsenal of empowerment means is used, is the view at a child as an equal person capable of producing interesting ideas, able to realize one's potential in learning and direct it to the creative mainstream. It is this person who wants a sustainable development and self-improvement.

An appeal to the mental code of a culture realized through the studies of the components of the "Divine Child" archetype within the collective unconscious is quite appropriate, since they are the expressions of the psychic energy that is synthesized by the person as noted by C. Jung. That is, the collective subconscious contains impersonal objectivity, which is determined by high intensity of the experience and culturally independent repetition. Thus, the archetype can be perceived as a sign of a kind of brace that holds the human being, family, nation, state, humanity as a whole, and therefore the study of the specifics of their functioning in various spheres of ethnic culture helps to overcome the socio-humanitarian crisis. The term "empowerment" literally 
means "inner strength", accumulation and realization of potential, inspiration, a way of realizing future hopes.

The dominant principle of the pedagogical empowerment through the prism of the sustainable development strategies is to form the desire of young people to take an active position in society, to influence the development of society, to strive for a harmonious and safe life.

Conclusions. The carried out observations have given us grounds to consider that the essence of empowering pedagogy is primarily in stimulating the semantic childhood center as an embodiment of the "puer" archetype (the cultural "grain of mankind") for the purposeful selection and its implementation into concrete results for the development of a new harmonious system. The program of sustainable development, as the leading modern ideology of human communities asserts the look at a child as an active person capable of generating ideas, aimed at creating a new harmonious reality realizing the new educational paradigm, consonant with the challenges of our time.

\section{REFERENCES}

1. Toffler A. (2004). Tretya volna [The Third Wave]. P. S. Gorelov (Eds.). Moscow: AST [in Russian].

2. Stratehiia staloho rozvytku Ukrainy na period do 2030 roku [Strategy of sustainable development of Ukraine for the period up to 2030]. (n.d.). www.ua.undp.org. Retrieved from http://www.ua.undp.org/content/ dam/ukraine/docs/SDGreports/ UNDP_Strategy_v06-optimized.pdf [in Ukrainian].
3. Osvita $v$ interesakh staloho rozvytku v Ukraini [Education for Sustainable Development in Ukraine]. (2016). ecoosvita.org.ua. Retrieved from http://ecoosvita.org.ua/storinkaknygy/osvita-dlya-stalogo-rozvytku [in Ukrainian].

4. Kovalenko T. (2014). Dytyna yak obiekt derzhavnoho upravlinnia u sferi sanatorno-kurortnoho zabezpechennia [The child as an object of state administration in the sphere of sanatorium and resort provision]. Derzhavne upravlinnia ta mistseve samovriaduvannia - Public administration and local self-government, 2 (21), 108-118 [in Ukrainian].

5. Donchenko, O. (2012). Vstup do "Arkhetypovoho menedzhmentu" [Introduction to "Archetype Management"]. Psykholohiia osobystosti Psychology of personality, 1, 195-203. Retrieved from http://nbuv.gov.ua/ UJRN/Po_2012_1_23 [in Ukrainian].

6. Freire P. (2003). Pedahohika pryhnoblenykh [Pedagogia do Oprimido]. (O. Demianchuko, Trans). Kyiv: Yunivers [in Ukrainian].

7. Telychko N. V. (2014). Teoretychni i metodychni zasady formuvannia osnov pedahohichnoi maisternosti maibutnikh uchyteliv pochatkovykh klasiv [Theoretical and methodical principles of forming the foundations of pedagogical mastery of future teachers of elementary school]. Doctor's thesis. Mukachevo: Mukachivskyi derzhavnyi universytet [in Ukrainian].

8. Jung C. (1991). Ob arkhetipakh kollektivnogo bessoznatelnogo [The Archetypes and the Collective Unconscious]. Arkhetip i simvol Archetype and Symbol. (p. 97128). Moscow: Reneissse [in Russian]. 


\section{СПИСОК ВИКОРИСТАНИХ ДЖЕРЕЛ}

1. Тоффлер Э. Третья волна / Элвин Тоффлер ; [науч. ред. П. С. Горелов]. - M. : ACT, 2004. - $781 \mathrm{c}$.

2. Стратегія сталого розвитку Украіни на період до 2030 року [Електронний ресурс]. - Режим доступу: http://www.ua.undp.org/content/ dam/ukraine/docs/SDGreports/ UNDP_Strategy_v06-optimized.pdf

3. Освіта в інтересах сталого розвитку в Україні [Електронний ресурс]. - Режим доступу: http:// ecoosvita.org.ua/storinka-knygy/ osvita-dlya-stalogo-rozvytku

4. Коваленко Т. Дитина як об'єкт державного управління у сфері санаторно-курортного забезпечення / Т. Коваленко // Держ. управління та місцеве самоврядування : зб. наук. пр. / голов. ред. С. М. Серьогін. Дніпропетровськ : ДРІДУ НАДУ, 2014. - Вип. 2 (21). - С. 108-118.
5. Донченко О. Вступ до "Архетипового менеджменту" / О. Донченко [Електронний ресурс] // Психологія особистості. - 2012. - № 1. C.195-203.- Режимдоступу: http:// nbuv.gov.ua/UJRN/Po_2012_1_23

6. Фрейре П. Педагогіка пригноблених / Пауло Фрейре; [пер. з англ. О. Дем'янчука]. - К. : Юніверс, 2003. - $168 \mathrm{c}$.

7. Теличко Н. В. Теоретичні і методичні засади формування основ педагогічної майстерності майбутніх учителів початкових класів : дис. ... д-ра пед. наук : спец. 13.00.04 - Теорія і методика професійної освіти / Мукачівський держ. ун-т. - Мукачево, 2014. -559 c.

8. Юнг К. Об архетипах коллективного бессознательного / К. Юнг // Архетип и символ. - М. : Reneisse, 1991. - C. 97-128. 